\title{
Effectiveness of a Biological Insecticide Derived from Scorpion Fish Offal against the Chickpea Weevil
}

Laribi-Habchi $\mathrm{H}^{1}$, Biche $\mathbf{M}^{2}$, Drouiche $\mathbf{N}^{1,3 *}$, Khalfi $\mathbf{W}^{2}$, Abdi $\mathbf{N}^{1}$ and Mameri $\mathbf{N}^{1}$

${ }^{1}$ National Polytechnic school of Algiers, B.P. 182-16200, El Harrach, Algiers, Algeria

${ }^{2}$ Institut National Agronomique d'Alger, El Harrach, Algeria

${ }^{3}$ Centre de Recherche en Technologie des Semi-conducteurs pour l'énergétique (CRTSE). 2, Bd Frantz Fanon BP140, Alger - 7 Merveilles, 16000, Algeria

\begin{abstract}
The aim of this study is to evaluate the biological activity of a crude chitinase extracted from fish offal (scorpion) on the chickpea weevil Callosobruchus maculatus (Coleoptera: Bruchidae) at various concentrations: $3 \%, 6 \%, 9 \%$, $12 \%, 15 \%, 18 \%, 21 \%$ and $24 \%$ (V/V). The biological tests were performed under the typical experimental conditions: temperature and relative humidity at $28^{\circ} \mathrm{C}$ and $75 \%$, respectively. The results have shown that the concentration of $24 \%$ of crude chitinase extracted has $100 \%$ of insecticide activity after a contact time of $1 \mathrm{~h}$. The lethal dose (LD50) is estimated for every sample and for a range time from 1 to $72 \mathrm{~h}$. The lower percentage of mortality $(10 \%)$ is obtained for low values of concentrations and contact time (dose of $3 \%$ of crude chitinase and $1 \mathrm{~h}$ of contact time). The maximum mortality rate is observed for the high values of two parameters (dose of $24 \%$ of crude chitinase and $72 \mathrm{~h}$ contact time). However, it is observed that for a higher dose (24\%) and for a lower contact time $(1 \mathrm{~h})$, the mortality rate increased rapidly. The novelty of this work consists in the use of a new bioinsecticide obtained from offal scorpion fish.
\end{abstract}

Keywords: Crude chitinase; Scorpion fish; Extraction; Bioinsecticide; Callosobruchus maculates

\section{Introduction}

Around the world, stored products are attacked by several species of pests. Chemical control against the various pests, using essentially conventional pesticides, continues to be the major means of protecting foodstuffs. Secondary effects of insecticides and environmental imperatives have encouraged the search for new approaches to protect these shifts. To fight against the food insecurity and to protect the environment, we should increase agricultural production through the judicious use of scientific and biotechnological tools. Leguminous seeds represent the main source of protein in many developing countries [1]. Unfortunately, they suffered considerable losses during storage [2]. The stored products can be destroyed by insects, fungi and rodents. Losses caused by insects are considerable in countries where modern techniques of storage are not yet introduced. Larvae of cleopter Bruchidae consume and grow only in the seeds of leguminous $[3,4]$. Also, the chickpea weevil Callosobruchus maculatus may infest the plant Cicer arietinum in fields and stocks, in addition it infects other leguminous non-host plants which have an economic importance in developing countries as cowpea (Vigna unguiculata) and sap (Vicia faba) [5].

Chemical control using synthetic insecticides has dominated control tactics against insect pests of stored products [6-8]. In this study a new bio-insecticide obtained from offal scorpion fish was utilized. For this purpose, chitinase was extracted from scorpion's stomach and tested as a protective film of chickpea weevil.

Experimental design and statistical analysis were utilized to study the effects of two independent variables, namely concentrations of crude chitinases $\left(\mathrm{X}_{1}\right)$ and contact time $\left(\mathrm{X}_{2}\right)$ on mortality rate of Callosobruchus maculatus. The planning of the experiments was carried out in order to evaluate the effects of the parameters and their interactions using the two levels factorial planning of the two studied variables $2^{2}$. A total of 8 experiments were formulated including $2^{2}$ full factorial design $( \pm 1)$ with four replicates at central point (coded level 0 ). The factors and the experimental domain of variation of factors (coded and uncoded levels) are given in Table1.
The functional relationship between the two independents variables $\left(\mathrm{X}_{1}, \mathrm{X}_{2}\right)$ and the response $(\mathrm{Y})$ is expressed by a first order polynomial function (Eq.1):

$$
Y=a_{0}+a_{1} X_{1}+a_{2} X_{2}+a_{1.2} X_{1} X_{2}(1)
$$

$\mathrm{Y}$ represents the mortality rate of Callosobruchus maculates, $\mathrm{X}_{1}, \mathrm{X}_{2}$ are independent variables representing the coded values of the factors according to Table $1, \mathrm{a}_{0}$ (center point of system) is the average of the results of the replicated central point, $a_{1}, a_{2}$ are coefficients of linear effects and $a_{1.2}$ is coefficient of interactive effect.

In the present work, the influence of the concentration of the crude chitinase and the contact time on the mortality rate of insects has been estimated.

\section{Material and Methods}

The insect cuticle is composed of chitin. Chitin is a polymer of $\mathrm{N}$-acetyl glucosamine and the second abundant component on the

\begin{tabular}{|l|c|c|c|}
\hline Parameter & $\begin{array}{c}\text { Lower level } \\
(\mathbf{- 1})\end{array}$ & $\begin{array}{c}\text { Higher level } \\
(+\mathbf{+ 1 )}\end{array}$ & $\begin{array}{c}\text { Centre } \\
\text { Co-ordinates (0) }\end{array}$ \\
\hline Doses of crude chitinases (\%) $\mathrm{X}_{1}$ & 3 & 24 & 14 \\
\hline Contact time $(\mathrm{h}) \mathrm{X}_{2}$ & 1 & 72 & 37 \\
\hline
\end{tabular}

Table 1: Domain of variation of the parameters for the factorial planning $2^{2}$.

*Corresponding author: Dr. Nadjib Drouiche, Technology of Semi-conductor for the Energetic Research Center, Department of Environmenta Engineering, 2, Bd Frantz Fanon BP140 Alger-7-merveilles, Algiers, Algeria, Tel: 21321279880 (Ext:192); Fax: 21321 433511; Email: nadjibdrouiche@yahoo.fr; droui2@unesco-ihe.org

Received Janaury 04, 2014; Accepted January 20, 2014; Published January 27,2014

Citation: Laribi-Habchi H, Biche M, Drouiche N, Khalfi W, Abdi N, et al. (2014) Effectiveness of a Biological Insecticide Derived from Scorpion Fish Offal against the Chickpea Weevil. J Bioprocess Biotech 4: 148 doi: 10.4172/2155-9821.1000148

Copyright: (c) 2014 Laribi-Habchi $\mathrm{H}$, et al. This is an open-access article distributed under the terms of the Creative Commons Attribution License, which permits unrestricted use, distribution, and reproduction in any medium, provided the original author and source are credited. 
surface of the earth after cellulose [9]. It is present in bacterial, yeasts and fungi cell walls [10]. In animal reign, chitin is essentially present in exoskeleton of arthropods, and cuticle, trachea, diaphragm, peritrophic membrane and exochorion of insect [11]. However, chitinases may be used as antagonist to pests. Chitinases (EC3.2.1.14) are enzymes that are widely distributed in nature and play an important part in degradation of chitin. They occur in many fishes where they are produced by the digestive glands for the digestion of chitinous foods [12]

\section{Choice of biological material and insects breeding}

The choice of chitinases from offal scorpion fish is due to their high enzymatic activity (40\%) compared to others fishes as Red mullet (24\%), burbot (14\%), bougue (13\%) and silt (5\%). Among the insects, Callosobruchus maculatus (chickpea weevil) has been chosen for several reasons: the species is cosmopolitan and infests stored products of economic importance in Algeria, and may be easily cultivated in laboratory for testing the efficiency of crude chitinase on a large number of individuals.

The insects were mass reared on chickpea in jars $(18 \mathrm{~cm}$ in height and $11 \mathrm{~cm}$ in diameter). The jars are kept at a controlled temperature $\mathrm{T}=28 \pm 2^{\circ} \mathrm{C}$, in obscurity and at a relative humidity of about $75 \pm 2 \%$.

\section{Extraction of crude extracts chitinase}

The samples were prepared at 1/6 ratio [13] in weight of offal per volume of buffer solution prepared from citric acid $(0.15 \mathrm{M})$ and disodium phosphate $(0.3 \mathrm{M})$ at $\mathrm{pH}$. The reaction mixture was incubated at $37^{\circ} \mathrm{C}$ during $3 \mathrm{~h}$ at $120 \mathrm{rpm}$.

At the end of the incubation, the macerated sample was filtered through a gauze fabric. The obtained filtrate was centrifuged at $6000 \mathrm{~g}$ during $30 \mathrm{~min}$. The recovered supernatant is the crude enzyme extract.

\section{Dosage of N-Acetyl-Glucosamine (NAG)}

The dosage of NAG was performed using Reissig method [14] modified by Gustowska et al. [15]. This technique requires a reagent $\mathrm{A}$, which is composed of potassium tetraborate solution $(0.8 \mathrm{M})$ adjusted to $\mathrm{pH} 9.1$ with $1 \mathrm{~N} \mathrm{KOH}$, and a reagent $\mathrm{B}$ involving $1.5 \mathrm{~g}$ of dimethylaminbenzaldehyde (DMAB) dissolved in $100 \mathrm{ml}$ of pure glacial acetic acid containing $1.25 \%$ of $\mathrm{HCl}(12 \mathrm{~N})$. The concentration of NAG was determined by adding $0.5 \mathrm{ml}$ of supernatant and a blank ( $0.5 \mathrm{ml}$ of distilled water) to $0.1 \mathrm{ml}$ of reagent $\mathrm{A}$.

The mixture was heated in a water bath at $100^{\circ} \mathrm{C}$ for about $3 \mathrm{~min}$ and then cooled in a cold water bath, followed by addition of $3 \mathrm{ml}$ of reagent $\mathrm{B}$ and homogenization of the solution. The samples were immediately incubated in a thermostatic bath at $37^{\circ} \mathrm{C}$ during $20 \mathrm{~min}$. The NAG concentration was determined using spectrophotometer at an amount of NAG liberated when chitin was incubated in presence of chitinases solutions. This concentration of NAG exposes the relative importance of process analysis of chitin on simple amines sugars [16].

One unit of chitinase activity (U) is defined as the amount of enzyme that releases $1 \mu \mathrm{g}$ of NAG per hour [17].

\section{Bioassays}

\section{Effect of contact}

Different concentrations of crude chitinase $3 \%(10.5 \mathrm{U} / \mathrm{ml}), 6 \%$ (12.4 U/ml), 9\% (29 U/ml), 12\% (31.6 U/ml), 15\% (49 U/ml), 18\% $(52 \mathrm{U} / \mathrm{ml}), 21 \%(69 \mathrm{U} / \mathrm{ml})$ and $24 \%(72 \mathrm{U} / \mathrm{ml})$ were deposited on Petri boxes with four replicates per dose. The sample is spread out, dried, and then ten couples of insects aged between 0 to $24 \mathrm{~h}$ were placed in each Petri box. The mortality rate was calculated after $1 \mathrm{~h}, 24 \mathrm{~h}, 48 \mathrm{~h}$ and $72 \mathrm{~h}$.

\section{Contact test on the treated seeds}

For each essay, $2 \mathrm{ml}$ of each sample of chitinase crude extract at various concentrations $(3 \%, 6 \%, 9 \%, 12 \%, 15 \%, 18 \%, 21 \%$ and $24 \%)$ were homogeneously dispersed in $100 \mathrm{~g}$ of seeds. The experiments were repeated three times. All batches of treated seeds were infested with 10 pairs of insects aged between 0 and $24 \mathrm{~h}$. The counting of dead insects is carried out after 1,24, 48 and $72 \mathrm{~h}$. The death recorded in batches of treated seeds was calculated and corrected for mortality in accordance with Abbott's formula [18] taking into account the natural mortality in samples.

\section{Bio essay of crude chitinase on larval feeding}

The method described by Xie [19] to measure chitinases effect on the insect feeding was utilized in our present work. A mix of $50 \mathrm{~g}$ of chickpea flour and $14 \mathrm{ml}$ of the lethal dose (24\%) was used for making meatballs the size of a chickpea. The seeds used for the control were made with chickpea flour and citrate buffer. The reconstituted seeds were dried for $24 \mathrm{~h}$ at a temperature of $30^{\circ} \mathrm{C}$ (to avoid distortion of chitinases and protein fractions) and at humidity of $75 \%$. Chickpeas well prepared were placed in Petri dishes of $14 \mathrm{~cm}$ diameter with 10 insects couples to obtain the eggs. The eggs laid were counted daily until the death of the females and placed in an oven to assess fertility. The experiment was repeated four times for each dose and for the control.

The number of died larvae found in treated population with those concentrations previously cited were counted. The percentage of mortality was calculated and corrected with the control mortality [18],

(Eq.2): $\mathrm{MC}(\%)=(\mathrm{M}-\mathrm{Mt}) /(100-\mathrm{Mt}) \times 100(2)$

$\mathrm{MC}$ is the percentage of the mortality corrected, $\mathrm{M}$ is the percentage of the mortality observed in the treated population and $\mathrm{Mt}$ is the percentage of the mortality in the control population. One way to test the effectiveness of a product is the calculation of Lethal Dose 50 (LD50) which corresponds to the amount killing 50\% of individuals of the same batch. It is deduced by drawing the regression line. The percentages of mortality were transformed into corrected probist were plotted as a function of natural logarithm of the LD50 which was determined from the Eq.2 of a straight line obtained theoretically [20].

The experimental design and the results evaluation were performed using Statistica Software (Stat Soft France Version 9.0).

\section{Results and Discussion}

\section{Evaluation of the effect of crude chitinase contact}

The obtained results show that crude chitinases manifests insecticidal activity by contact. The percentages of mortality obtained ranged from 10 to $100 \%$ after only $1 \mathrm{~h}$ of contact. The control gave a percentage of mortality close to $0 \%$ (Figure 1 ). Other studies [21] using essential oils from aromatic plants were carried out on the same pest. Melaleuca quinquenervia, Citrus aurantifolia and rosemarinus officinalis revealed mortality rate of $60 \%, 48 \%$ (After a $24 \mathrm{~h}$ treatment) and $25 \%$ (after $96 \mathrm{~h}$ of treatment) respectively. The biopesticide produced in this study appeared more efficient than the essential oils reported in literature.

The results were confirmed by observation of scanning electron microscope SEM (JEOL 6360). Indeed, the deterioration of the insect's 
Citation: Laribi-Habchi H, Biche M, Drouiche N, Khalfi W, Abdi N, et al. (2014) Effectiveness of a Biological Insecticide Derived from Scorpion Fish Offal against the Chickpea Weevil. J Bioprocess Biotech 4: 148 doi: 10.4172/2155-9821.1000148

Page 3 of 4

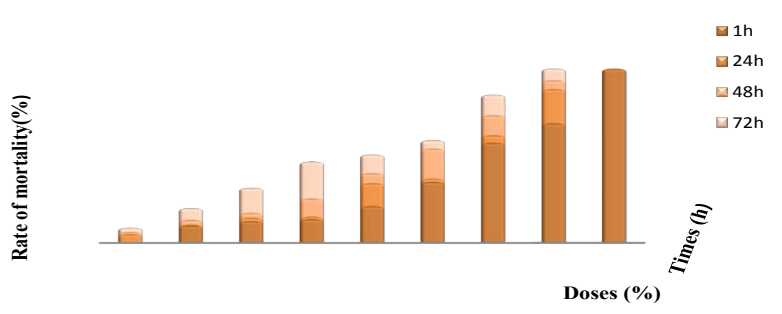

Figure 1: Evolution of percentage mortality (\%) of Callosobruchus maculatus against doses of crude extract chitinase (\%) and contact time (hours).

(a)

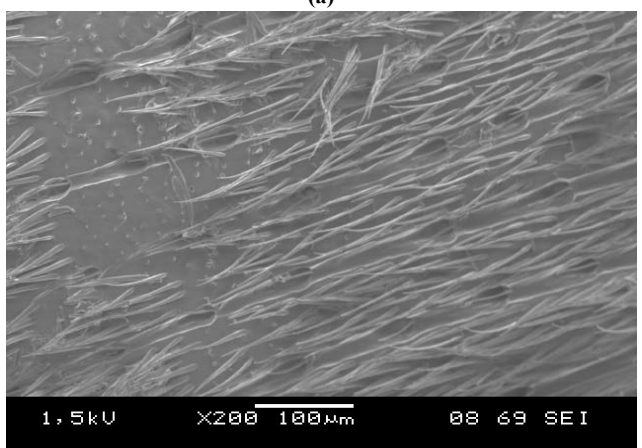

(b)

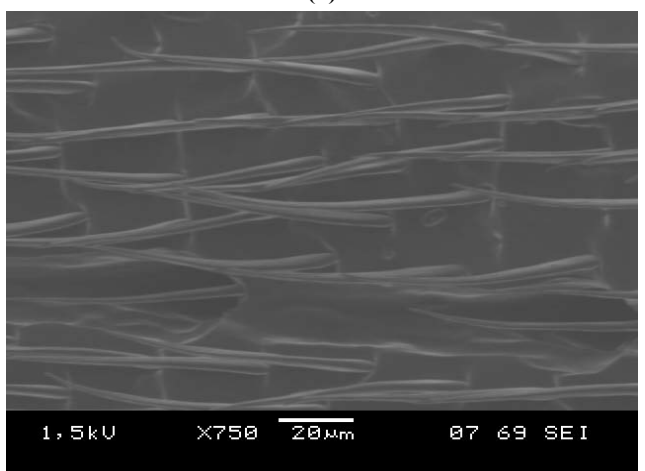

Figure 2: SEM image of a Callosobruchus maculates elytron (a):treated by contact with the lethal dose $(24 \%)$ of crude chitinas, (b): control.

cuticule by the crude chitinases compared to control (Figure 2) was observed.

The LD50 of crude chitinases obtained against the contact time ranging from 1 to $72 \mathrm{~h}$ were close to $14 \%$. Indeed, LD50 of $5 \%(1 \mathrm{~h}$ of contact), $15 \%$ ( $24 \mathrm{~h}$ of contact), 14\% (48 h of contact) and 13\% (72 $\mathrm{h}$ of contact) were obtained (Figure 3). However, for Callosobrochus maculatus, in all studies undertaken the essential oils have been used.

\section{Contact test on the treated seeds and larval feeding}

The results obtained after contact tests on the treated seeds showed similar mortality percentages compared to the previous experiments. Nevertheless, chitinases extracted raw from fish offal was very toxic against Callosobruchus maculatus with $100 \%$ of mortality rate at a dose of $24 \%$ after $24 \mathrm{~h}$ (Figure 4 ). Low doses (3\%, 6\%, 9\% and $12 \%)$ showed a less active insecticidal effect.

To evaluate the effect of chitinase on larval feeding, five days treatment, all eggs laid entered reconstructed seeds. The results obtained show that after 10 days, all the larvae died after leaving the seeds. In the control, the rate of emergence is about $95 \%$ was obtained.

\section{Experiments planning study}

The matrix of the experimental design and the experimental results are shown in Table 2. By comparing the different obtained mortality rates, the mortality is mostly affected by the dose's variation of crude chitinases (\%) and the contact time (h).

The lower percentage of mortality (10\%) is obtained for low values of concentrations and contact time (dose of $3 \%$ of crude chitinase and $1 \mathrm{~h}$ of contact time). The maximum mortality rate is observed for the high values of two parameters (dose of $24 \%$ of crude chitinase and 72 h contact time). However, it is observed that for a higher dose (24\%) and for a lower contact time $(1 \mathrm{~h})$, the mortality rate increased rapidly.

Table 3 presents the statistical significance of each effect of model's effect. According to the regression analysis, effects lower than 0.05 in the $\mathrm{P}$-value column $(95 \%$ confidence level) is significant $(\mathrm{P}<0.05)$. In this case, it can be seen that the dose of crude chitinases was the most important influence on the mortality rate of Callosobruchus maculatus.
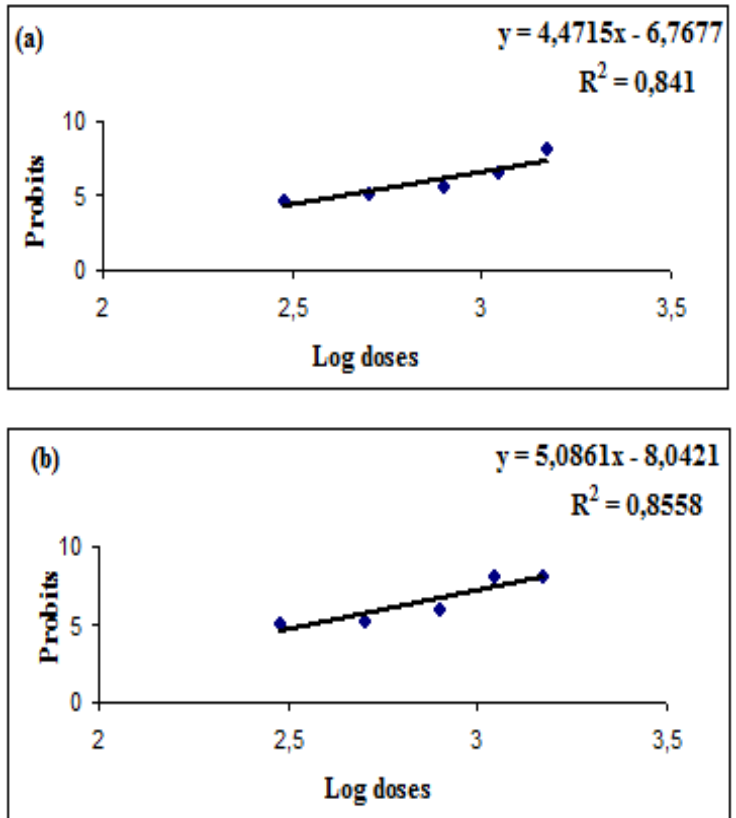

Figure 3: Regression curves: (a): after $24 \mathrm{~h}$ of contact, (b): after $48 \mathrm{~h}$ of contact.

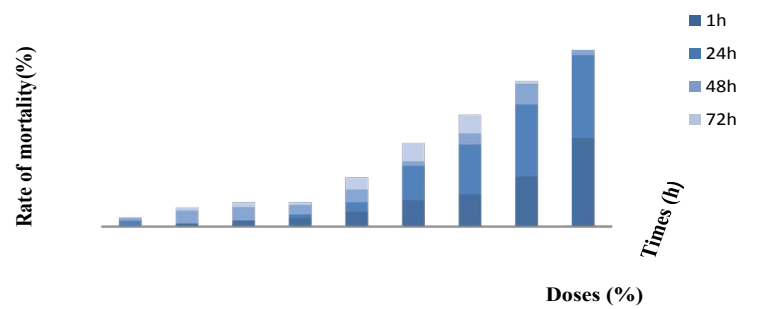

Figure 4: Evolution of percentage mortality (\%) of Callosobruchus maculatus at different doses of crude extract chitinase (\%) and contact time (hours): contact test on the treated seeds. 
Citation: Laribi-Habchi H, Biche M, Drouiche N, Khalfi W, Abdi N, et al. (2014) Effectiveness of a Biological Insecticide Derived from Scorpion Fish Offal against the Chickpea Weevil. J Bioprocess Biotech 4: 148 doi: 10.4172/2155-9821.1000148

Page 4 of 4

\begin{tabular}{|c|c|c|c|}
\hline Run $\mathbf{n}^{\circ}$ & $\begin{array}{c}\text { Doses of crude } \\
\text { chitinases (\%) }\end{array}$ & Contact time (h) & $\begin{array}{c}\text { Mortality rate of } \\
\text { Callosobruchusmaculatus (\%) }\end{array}$ \\
\hline 1 & -1 & -1 & 10 \\
2 & +1 & -1 & 100 \\
3 & -1 & +1 & 12.33 \\
4 & +1 & +1 & 100 \\
5 & 0 & 0 & 33 \\
6 & 0 & 0 & 40.8 \\
7 & 0 & 0 & 37 \\
8 & 0 & 0 & 39.5 \\
\hline
\end{tabular}

Table 2: Experimental design and observed responses.

\begin{tabular}{|c|c|c|c|c|c|}
\hline & Coefficient & Statistic (t) & Statistic (t) & $\begin{array}{c}\text { Limit } \\
\text { confidante } \\
\mathbf{( - 9 5 \% )}\end{array}$ & $\begin{array}{c}\text { Limit } \\
\text { confidante } \\
\mathbf{( + 9 5 \% )}\end{array}$ \\
\hline $\begin{array}{c}\text { Constant } \\
\mathrm{X}_{1}\end{array}$ & 46.57875 & 10.0754 & 10.0754 & 33.7432 & 59.41425 \\
$\mathrm{X}_{2}$ & 0.58250 & 6.79384 & 6.79384 & 26.2654 & 62.56964 \\
$\mathrm{X}_{1} \mathrm{X}_{2}$ & -0.58250 & -0.08910 & 0.08910 & -17.5696 & 18.73464 \\
& & -0.08910 & -18.7346 & 17.56964 \\
\hline
\end{tabular}

Table 3: Effects of the coefficient of the model.

\begin{tabular}{|c|c|c|c|c|c|}
\hline & Sum square & $\begin{array}{c}\text { Freedom } \\
\text { degree }\end{array}$ & Mean square & F & $\boldsymbol{P}$ \\
\hline Regression & 7894.372 & 3 & 2631.457 & 15.390072 & 0.011596 \\
\hline Résidu & 683.9076 & 4 & 170.9769 & & \\
\hline Total & 8578.2796 & 7 & & & \\
\hline
\end{tabular}

$R^{2}=0.920274$, Adjusted $R^{2}=0.860480$

Table 4: Analysis of variance.

The contact time and the interaction between the crude chitinase dose and the contact time were not statistically significant on the response.

The analysis of variance was used for testing the significance of the model, thus various statistical data such as sum of square. F-ratio and $\mathrm{p}$-value are given in Table 4.

The P-value for regression in the ANOVA table is less than 0.05 , which means that the model appears to be adequate for the observed data at the $95 \%$ confidence level.

The coefficient of determination $\left(\mathrm{R}^{2}\right)$ of the model was 0.920274 , indicating that the model adequately represented the real relationship between the chosen parameters.

The value of adjusted $\mathrm{R}^{2}(0.860480)$ suggests that the total mortality rate variation of $86 \%$ is attributed to the independent variables, and only about $14 \%$ of the total variation cannot be explained by the model.

The influence of the doses and the time on the mortality percentage obtained from the model is represented by the following Eq.3:

$$
\mathrm{Y}=46,57+44,41 \mathrm{X}_{1}+0,58 \mathrm{X}_{2}-0,58 \mathrm{X}_{1} \mathrm{X}_{2}(3)
$$

The response surface obtained from this equation is presented in Figure 5 in order to show the behaviour of the mortality rate during experiments.

The response surface plot which gives the mortality rate (\%) as a function of dose of crude chitinase and the contact time, shows that the mortality rate increases with augmentation of crude chitinase dose and contact time.

\section{Conclusion}

The insects were sensitive to biological tests. The crude chitinase extract was used as a biological insecticide and its effect is related to the dose and to the contact time. Thus, the approaches were designed to determine the effectiveness of crude chitinases contact. Interesting results are obtained for $100 \%$ of insecticide activity after $1 \mathrm{~h}$ contact at a dose of $24 \%$.

The difference noted in the mortality rate of the insects at different doses attracts us to investigate many other aspects in this field. It would be appropriate to extend these trials to all other insects attacking leguminous seeds stocks and other grains such as Sitophilus oryzae, to effectively assess their actual action in stored-product protection.

\section{References}

1. Boutin JP, Dronne Y, Ducournau S, Gueguen J, Leguen, J, et al. (2006) Les protéagineux. INRA.

2. Erler F, Ceylan F, Erdemir T, Toker C (2009) Preliminary results on evaluation of chickpea, Cecerarietinum, genotypes for resistances to the pulse beetle, Callosobruchusmaculatus. J Insect Sci 9:1-7.

3. Kellouche A, Soltani N (2004) Activité biologique des poudres de cinq plantes et de l'huile essentielle d'une d'entre elles sur Callosobruchusmaculatus (F). Inter J Trop Insect Sci 24: 184-191.

4. Zhou J, Zeng X, Zheng K, Zhu X, Ma L, et al. (2012) Musks and organochlorine pesticides in breast milk from Shanghai, China: Levels, temporal trends and exposure assessment. Ecotoxicol Environ Saf 84:325-333.

5. Regnault R, Hamraoui $A(1997)$ Lutte contre les insectes phytophages par les plantesaromatiques et leurs moleculesallélo chimiques. Edacta Bot Gallica: 401-412.

6. Yang D, Qi S, Zhang J, Wu C, Xing C (2012) Organochlorine pesticides in soil, water and sediment along the Jinjiang River mainstream to Quanzhou Bay, southeast China. Ecotoxicol Environ Saf 89: 59-65.

7. Karabelas AJ, Plakas KV, Solomou ES, Drossou V, Sarigiannis DA (2009) Impact of European legislation on marketed pesticides. A view from the stand point of health impact assessment studies. Environ Inter 35: 1096-1107.

8. Plakas KV, Karabelas AJ (2012) Removal of pesticides from water by NF and RO membranes - A review. Desalination 287: 255-265.

9. Anil K, Seshagirirao K, Podile AR (2007) A simple, rapid and yet less expensive method to detect chitinase in agarose plates. J BiochemBiophys Met 70: 683-684.

10. Baldrian P, Viriskova J, Dobiasova P, Merhautova V, Ludmila L, et al. (2011) Production of extracellular enzymes and degradation of biopolymers by saprotrophic microfungi from the upper layers of forest soil. Plant Soil 338: 111-125.

11. Jasrapuria S, Arakane Y, Osman G, Kramer KJ, Beeman RW, et al.(2010) Gene encoding protein with peritrophin a type chitin binding domains in Triboliumcastaneumare grouped in to three distinct families based on phylogeny, expression and function. Insect Biochem Molecul Biol 40: 214-227.

12. Neetu D, Tewari R, Hoondal GS (2006) Biotechnological aspects of chitinolytic enzymes a review. Appl Microbiol Biotechnol 71: 773-782.

13. Ikeda M, Miyauchi K, Mochizuki A, Matsumiya M (2009) Purification and characterization of chitinase from the stomach of silver croaker Pennahiaargentatus. Protein Expression Purif 65: 214-222.

14. Reissig JL, Strominger JL, Leloir LF (1955) A modified calorimetric method for the estimation of $\mathrm{N}$-acetylamino-sugars. J BiologChem 217: 959-966.

15. Gustowska MA, Drazen JC, Robison BH (2004) Digestive chitinolytic activity in marine fishes of Monterey Bay,California.CompBiochemPhysiol A Mol IntegrPhysiol 208: 351-358.

16. Jeuniaux C (1963) Chitine et chitinolyse. Masson (Eds.), Paris.

17. Fines J, Holt GJ (2010) Chitinase and apparent digestibility of chitin in the digestive tract of Juvenile cobia, Rachycentroncanadum. Aquaculture 303:34-39.

18. Abbot SW (1925) A method of computing the effectiveness of an insecticide. J Economic Entomol 18: 265-267.

19. Xie YS, Bodnaryk RP (1996)A rapid and simple flour disk bioassay for testing natural substance active against stored product insect. CanadEntomolog128: $865-875$.

20. Finney DJ (1971)Probit analysis, (3rd Ed.), Cambridge University Press.

21. Nondenot A, Louis R, Boudama P, Seri-Kouassi K, Kouakou H (2010) L'activité insecticide des huiles essentielles de trois plantes aromatiques sur Callosobruchus maculatus F en Cote d'Ivoire. J Europ Recher Sci 39: 243-250. 